\title{
An Exploration of the Impact of Digital Marketing on SMEs Growth and Brand Popularity in Rural South Africa
}

\author{
Lawrence Mpele LEKHANYA \\ Durban University of Technology, South Africa \\ Lawrence@dut.ac.za
}

\begin{abstract}
The purpose of the study is to establish understand of digital marketing and its use by SMEs in rural South Africa, the extent of its use, examining contributing factors to its use and their implications. Primary data was collected using a quantitative research technique with the use of a structured questionnaire as the survey instrument. A total of 134 SMEs operating in rural KwaZulu -Natal were selected. Questionnaires were distributed to the business owners/ mangers between august and December 2014. SPSS (22.0) version was employed to for data analysis. The findings of this study revealed that some rural places in South Africa still experiencing ICT problems for being not available make it difficult for SMEs growth through the use of digital marketing. The reliability analysis, reflected coefficient values from 0.70 to 0.833 . The analysis of factors limiting use of digital marketing among the rural SMEs, are presented with recommended strategies and implications on how to approach the challenges. Digital marketing of rural SMEs may be strengthened through awareness and providing adequate information about ICT and through diverse of internet marketing programmes.
\end{abstract}

Keywords: Digital marketing; exploration; brand popularity; rural; SMEs

\section{Introduction}

Since the beginning of emerging of new technologies including digital, networking as well as social media business environment has drastically change. The interception of these has also change the marketing landscape all over the world as many business conduct their marketing communications with customers through digital marketing (Lekhanya, 2014). This view echoed by the e agency (2015) that gone are the days of relying on costly and time consuming traditional marketing methods such as print advertising and direct mail as this are sharing the platform with digital marketing which is new ways of communicating online with customers. According to Jagongo \& Kinnyua (2013), it has become important for the business owners and marketers to understand how social media work as a communication and marketing tool and how they can significantly grow their businesses. Digital marketing tools such social media, today, is among, the best opportunities available to a brand for connecting with prospective consumers (Neti, 2011). However, a remote rural location is shown to influence innovation in different aspects of the business in different ways (North \& Smallbone, 2000). Thus means that the use digital marketing tools are likely to be low in South African rural areas.

Problem statement: it has been noticed that although larger companies are benefiting impressively from adopting a mobile marketing strategy, the uptake from small business is still very low (Elvin web marketing, 2015). Literature indicates that many businesses are experiencing tremendous pressure to extend to where their customers are paying attention (Jagongo \& Kinnyua (2013). Baird \& Parasni (2011, in Jagongo \& Kinnyua, 2013) support the premise that in the present day, the heart of customer activity is progressively becoming virtual, situated inside a social media or social networking. According to Valliere, 2010), important in entrepreneurial are the requirements of good management practices in particular in relation to marketing functions, communications, technology and perception of opportunities since these aspects can influence the rate of entrepreneurial firm development. However, it is not yet understood how these concepts may operate in the digital marketing context of rural SMEs with specific reference in South Africa. 


\section{Aims and objectives}

Aims: The paper seeks to examine the understanding and knowledge of digital marketing, use and its implications on the marketing strategies of rural South Africa, with specific reference to KwaZulu - Natal.

\section{Objectives}

- To establish rural SMEs owners/managers are understanding and knowledge of digital marketing strategies in KZN;

- To assess the extent they use digital marketing to promote their brands in KZN; and

- To find the implications of digital marketing on the rural SMEs brand popularity in KZN

\section{Literature Review}

Definition of Digital marketing: Clarke (2015) defines digital marketing as any activity that is carried out over the internet which aims to market products and services to identified target customer. This includes anything from email marketing, using website to attract new customers, content marketing or even using mobile platform or social networks. Wertime \& Fenwick (2008) describe digital marketing as the future evolution of marketing, which happens when the majority or totality of a company's marketing, uses digital channels. Furthermore, digital marketing refers to the use of all kinds of digital and social media tools that allow companies to foster interactions with customers (Järvinen, Tollinen, Karjaluoto \& Jayawardhena, 2012).

Understanding the relevance of digital marketing in survival and growth of rural SMEs: Wertime\& Fenwick (2008) stress that the shift from mass broadcast to digital, one-to-one media means that the traditional advertising algorithm of building brand image primarily through paid reach and frequency must be re-thought. The SMEs owner/managers should understand the important of internet in the business growth as it enable greater access to markets, advice and guidance, marketing opportunities and cost savings than previously feasible (Young, 2013). Clarke (2015) maintains that since the digital marketing landscape is changing all the time and this is where smaller businesses definitely have the upper hand because they have the flexibility to change more easily and adapt to their surroundings. Digital marketing consists of measures and activities to promote products and services and build relationships with customers over the internet (Kotler, 2010: 493).

Growth of digital marketing in rural South Africa: It has been indicated that even although digital and media within South Africa has been on the rise, the bone of contention is still the digital divide. These uncapped free Wi-Fi and a high mobile penetration in many establishments and homes, the rural population of South remains disconnected and may continue to be some for some time due to the overarching socio economic problems that face majority of population (Swanepoel, 2013)

The benefits of digital marketing for SME businesses :The e agency (2015) points that digital marketing relies on strategies that work well across the internet and mobile devices for businesses with big plans and small budgets that has many benefits such as cost-effective, real-time results, building more engaging relationships and it is easy to measure results.

Barriers to the use of digital marketing by South African rural SMEs: Cruz \& Fill (2008) mention technology incompatibility with target markets, lack of knowledge, stakeholder unreadiness, technology disorientation and technology perception as the major impediments towards the non-adoption of emarketing. These sentiments echoed by Järvinen, Tollinen, Karjaluoto \& Jayawardhena (2012), the firms lack the human resources and know how to make the most of opportunities provided by the developing digital environment. In particular, the lack of control of marketing messages and their distribution is considered a major risk when using social media tools as part of the digital marketing mix (Cruz \& Fill, 2008). However, the difficulty of determining return on investment (ROI) has been noted as one of the major barriers to investing in digital marketing (Marshall, Sor \& McKay, 2000). The disadvantages of digital marketing include lack of personal contact, security and privacy (Bostanshirin, 2014). 


\section{Methodology}

The study was conducted in different rural places in rural KwaZulu - Natal areas, which include north and south of province of KwaZulu-Natal. A comprehensive literature was conducted and used as sources of questionnaire formulation. 134 SMEs were asked to complete 10 page questionnaires to get empirical data for this survey. A Closed - ended questionnaire with 5 likert scale were distributed to the SMEs owners/managers business premises with the aid of research assistants. Prior appointments were made through telephone. The respondents were giving 14 days to complete questionnaire. Data was purely quantitative, and it was analysed by the use of Statistical Package for the Social Sciences (SPSS) program (version) 22 to test the significance of the results and later presented in the tables.

Table 1: Summary of key questions

\begin{tabular}{|c|c|}
\hline Research area & Questions \\
\hline Knowledge and understanding of & Digital marketing define as : \\
\hline Digital marketing & $\begin{array}{l}\text { Alternative response: The promotion of products or brands that } \\
\text { use one or more forms of electronic media; } \\
\text { Advertising mediums that use electronic; marketing strategy } \\
\text { of a business that include electronic; Internet marketing; all } \\
\text { promotional efforts that include internet, social media, mobile } \\
\text { phones, and electronic billboards, television and radio } \\
\text { channels. }\end{array}$ \\
\hline
\end{tabular}

Use of digital marketing

Benefits of digital marketing

Factors contributing to the use of Digital marketing

Attitude of Digital marketing

Methods of Digital marketing

Implications of Digital marketing

\section{The use of digital marketing depends of the availability of : \\ Alternative response: communication services; financial resources; Broad band services; Relevant skills and knowledge; internet marketing skills. \\ Business benefits from the following for using Digital marketing: \\ Alternative response: business reaches more customers; business brand popularity increases; business get more customer referrals; business sales volume increases; business maintains customer loyalty.}

\section{The following factors affect the use of Digital marketing :} Alternative response: social factors; economic factors; Technology factors; political factors; legal factors.

SMEs attitude of Digital marking is:

Alternative response: Internet very expensive; too much time required for Internet; business can do without; Internet marketing needs special skills.

Most used Digital marketing methods are:

Alternative response: Email marketing; Social media; Text messaging; Viral marketing; Affiliate marketing

SMEs in rural places increase their brand popularity through the use of Digital marketing.

Alternative response: Minimize costs; promote brand; reduce advertising costs. 


\section{Research findings}

Table 1: Knowledge and understanding of Digital marketing

\begin{tabular}{|c|c|c|}
\hline Variable & Frequency & Percentage \\
\hline $\begin{array}{l}\text { The promotion of products or brands that use one or more forms } \\
\text { of electronic media }\end{array}$ & 17 & $13 \%$ \\
\hline Advertising mediums that use electronic & 10 & $8 \%$ \\
\hline Marketing strategy of a business that include electronic & 7 & $5 \%$ \\
\hline Internet marketing & 70 & $52 \%$ \\
\hline $\begin{array}{l}\text { All promotional efforts that include internet, social media, mobile } \\
\text { phones, and electronic billboards, television and radio channels }\end{array}$ & 30 & $22 \%$ \\
\hline
\end{tabular}

As shown in table 1, 17(13 percentage) of respondents state digital marketing as the promotion of products or brands that use one or more forms of electronic media. 10 (8 percentage) indicate it as advertising mediums that use electronic. 7(5 percentage) define it as marketing strategy of a business that include electronic. While large number of respondents $70(52$ percentage) indicated it as Internet marketing, followed by $30(22$ percentage) mention it as all promotional efforts that include internet, social media, mobile phones, and electronic billboards, television and radio.

Table 2: Use of digital marketing

\begin{tabular}{lll}
\hline Variable & Frequency & Percentage \\
\hline Communication services & 7 & $5 \%$ \\
Financial resources & 80 & $60 \%$ \\
Broad band services & 13 & $10 \%$ \\
Relevant skills and knowledge & 23 & $17 \%$ \\
Internet marketing skills & 11 & $8 \%$ \\
\hline
\end{tabular}

The results, as shown in table 2 , indicate that $7(5$ percentage $)$ of respondents said use of digital marketing limited by lack of communication services. 80(60 percentage) indicated that financial resource is the problem to the use of digital marketing. 13(10 percentage) indicate broad band services as the challenge for the use of digital marketing. 23(17 percentage) show relevant skills and knowledge as a problem for the use of digital marketing. While 11(8 percentage) indicated availability of internet as a problem.

Table 3: Benefits of digital marketing

\begin{tabular}{lll}
\hline Variable & Frequency & Percentage \\
\hline Business reaches more customers & 98 & $73 \%$ \\
Business brand popularity increases & 8 & $6 \%$ \\
Business get more customer referrals & 15 & $11 \%$ \\
Business sales volume increases & 8 & $6 \%$ \\
Business maintains customer loyalty & 5 & $4 \%$ \\
\hline
\end{tabular}

The results, as indicated in table 3, illustrate that 98 (73 percentage) of the respondents believe that business researches more customers by the use of digital marketing. While on the other hand very few respondents highlight other benefits such as business brand popularity increase, business gets more customer referrals, business sales volume increases, and business maintains customers' loyalty.

Table 4: Factors contributing to the use of Digital marketing

\begin{tabular}{lll}
\hline Variable & Frequency & Percentage \\
\hline Social factors & 10 & $7 \%$ \\
Economic factors & 67 & $50 \%$ \\
Technology factors & 40 & $30 \%$ \\
Political factors & 10 & $7 \%$ \\
Legal factors & 7 & $5 \%$ \\
\hline
\end{tabular}


Table 2 shows that economic factors 67(50 percentage) and 40(30 percentage) respondents believe they are the most factors contributing to the use of digital marketing. While other factors indicated to be contributing very little to that effect.

Table 5: Attitude of Digital marketing

\begin{tabular}{lll}
\hline Variables & Frequency & Percentage \\
\hline Internet very expensive & 78 & $58 \%$ \\
Too much time required for Internet & 15 & $11 \%$ \\
Business can do without & 20 & $15 \%$ \\
Internet marketing needs special skills & 21 & $16 \%$ \\
\hline
\end{tabular}

The result, as indicated in table 5, illustrate that 78 (58 percentage) respondents indicated that Internet very expensive. Too much time required for Internet, business can do without and Internet marketing needs special skills have less attitude of digital marketing.

Table 6: Methods of Digital marketing

\begin{tabular}{lll}
\hline Variable & Frequency & Percentage \\
\hline Email marketing & 23 & $17 \%$ \\
Social media & 65 & $49 \%$ \\
Text messaging & 30 & $22 \%$ \\
Viral marketing & 10 & $8 \%$ \\
Affiliate marketing & 6 & $5 \%$ \\
\hline
\end{tabular}

Table 5 shows that social media 65(49 percentage) and 30(22 percentage) are the most methods of digital marketing used. While other methods account less percentages.

Table 7: Implications of Digital marketing

\begin{tabular}{lll}
\hline Variable & Frequency & Percentage \\
\hline Minimize costs & 11 & $8 \%$ \\
Promote brand & 45 & $34 \%$ \\
Reduce advertising costs & 78 & $58 \%$ \\
\hline
\end{tabular}

As shown in table 7, most respondents indicate that 78(58 percentage) reduce advertising costs and 45(34 percentage) promote brand. Very few 11 (8 percentage) indicate that digital marketing minimize costs.

Limitations: this study did not cover large number of the respondents. Therefore, generalization of these results should be done with care. Due to the complexity of South African geographical profile, further research needs to be done to cover more entrepreneurs.

Research implications: The findings of this study revealed that large numbers of respondents do not have clear knowledge and understanding of digital marketing and how it can benefit their business popularity. Therefore, the practical implications of this study will benefit all South African entrepreneurs and potential entrepreneurs.

\section{Conclusion}

Based on the findings, this study concludes that there are negative perceptions of Internet marketing being expensive and there is the feeling among respondents that digital marketing needs special skills.

\section{References}

Bostanshirin, S. (2014). Online marketing: challenges and opportunities, http://www.academia.edu/8512383/ONLINE_MARKETING_CHALLENGES_AND_OPPORTUNITIES (accessed 14/04/2015). 
Clarke, P. (2015). Digital marketing strategy.http://www.portsmouth-marketing.com/sme-digitalmarketing/(08/04/2015)

Cruz, D. \& Fill, C. (2008).Evaluating viral marketing: isolating the key criteria. Marketing Intelligence \& Planning, 26 (7), 743 - 758

Elvin web marketing. (2015). The Benefits of a Mobile App for Small Business in 2015. http://onlinemarketinginct.com/2015/01/15/benefits-mobile-app-small-business-2015/ (08/04/2015).

Järvinen, J., Tollinen, A., Karjaluoto, H. \& Jayawardhena, C. (2012). Digital and social media marketing usage in b2b industrial section. The Marketing Management Journal, 22(2), 102 -117

Jagongo, A. \& Kinyua, G. (2013). The Social Media and Entrepreneurship Growth. International Journal of Humanities and Social Science, 3(10) [Special Issue May 2013]

Kotler, P. (2010). Marketing for Hospitality and Tourism. $5^{\text {th }}$ edition. New Jersey: Pearson PrenticeHall.

Lekhanya, L. M. (2014) the Significance of Emerging Technologies in Promoting Internationalization of Rural SMEs in South Africa. Mediterranean Journal of Social Sciences, MCSER Publishing, Rome-Italy, 5(20).

Marshall, P., Sor, R. \& McKay, J. (2000). An industry case study of the impacts of electronic commerce on car dealerships in eastern Australia. Journal of Electronic Commerce Research, 1, 1-12

Neti , S. (2011). Social media and its role in marketing. International Journal of Enterprise Computing and Business Systems, 1(2).

North, D. \& Smallbone, D. (2000). The Innovativeness and growth of rural SMEs during the 1990s. Regional studies, 34 (2), 145-157.

Swanepoel, K. (2013). The growth of digital media and marketing in South Africa. http://synergizeonline.net/bookmark-awards/growth-digital-media-marketing-south-africa/ (07/04/2015).

The e agency. (2015). The benefits of digital marketing for SME businesses. http://www.theeagency.co.uk/benefits-digital-marketing-sme-businesses/ (08/04/2015).

Valliere, D. (2010). Reconceptualising entrepreneurial framework conditions. International Entrepreneurship and Management Journal, 6, 97-112.

Young, L. (2013). Growing young business. https://www.gov.uk/government/uploads/system/uploads/attachment_data/file/198165/growing -your-business-lord-young.pdf (07/04/2015) .

Wertime, K. \& Fenwick, I. (2008). Digital marketing: The essential guide to new media \& Digital marketing, John \& Sons. 